\title{
PRIMEIRA PALAVRA
}

A nova política cultural implantada na Universidade de São Paulo não poderia prescindir de um veículo que estabelecesse uma ligação mais estreita com a Sociedade. Por isso resolvemos buscar na própria história da USP uma publicação com essas características e encontramos, nos anos 50, 0 primeiro e único número da Revista da Universidade de São Paulo.

Resolvemos dar prosseguimento a este projeto iniciado há mais de três décadas. Com isto, pretendemos deixar claro que o reerguimento que propomos deve também resgatar as nossas raizes.

A Revista da Universidade de São Paulo projetará o pensamento acadêmico com o objetivo de influir no debate das grandes questões nacionais. Dará conta das atuais preocupações dos seus especialistas e traduzirá para a coletividade as linhas de pesquisa em desenvolvimento.

Cumprindo esses objetivos, ela ocupará um espaço importante no debate estabelecido pelo saber acadêmico no interior de um palco mais amplo. E é nesse palco, constituído por toda a Sociedade, que a produção estimulará essa dinâmica enriquecedora.

Para essa tarefa conto com a participação de toda a Universidade. As respostas aos primeiros convites foram tão imediatas e entusiasmadas que permitem prever, com certeza, a continuidade e o sucesso da Publicação.

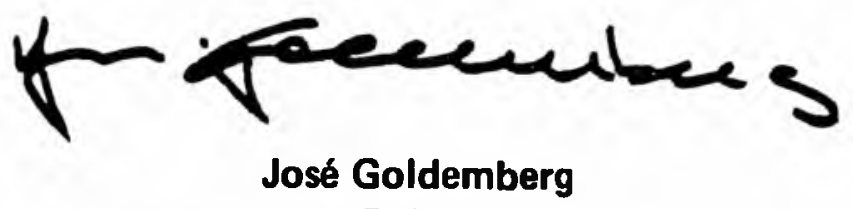

Reitor 